\title{
CYP1A1 wt Allele
}

National Cancer Institute

\section{Source}

National Cancer Institute. CYP1A1 wt Allele. NCI Thesaurus. Code C52323.

Human CYP1A1 wild-type allele is located within 15q22-q24 and is approximately $6 \mathrm{~kb}$ in length. This allele, which encodes cytochrome P450 1A1 protein, plays a role in the metabolism of polyaromatic hydrocarbons (PAHs). Individuals with a high-inducibility phenotype, who exhibit elevated CYP1A1 gene expression in response to PAHs, may be at greater risk for cig arette smoke-induced bronchogenic carcinoma. 